\title{
Evaluasi Penataan Interior Kelas dalam Pembentukan Perilaku Anak di KBTK Islam Sakha Sidoarjo
}

\author{
Mega Ayundya Widiastuti \\ Program Studi Arsitektur Universitas Islam Negeri Sunan Ampel Surabaya, Jawa Timur, Indonesia \\ m_ayundya@yahoo.com \\ doi.org/ 10.29080/emara.v4i1.323
}

\begin{abstract}
Early childhood education is an essential stage for the development of children's ability to attend school. Early age is the best phase for children to receive stimulation as well as their character formation in the future. The physical environment plays a vital role in supporting the successful establishment of children's behavior. One of them is through the design of classrooms that are suitable for the child's world. This study attempted to evaluate the interior arrangement of the school in the formation of children's behavior along with its influence on children's behavior in the Sakha Islamic Play Group / Kindergarten. This study uses a descriptive method with a qualitative approach and observation techniques on various aspects of the class physical arrangement. The results of the study concluded that some elements of the interior provision of classes in the Sakha Islamic Play Group / Kindergarten, such as the visibility and comfort, were not in accordance with the standards, while the classroom interior arrangement had influenced the children's behavior with the barrier mechanism and invited some specific children behaviors to shape their personality.
\end{abstract}

Keywords: class interior arrangement, children behaviour, Kindergarten

\begin{abstract}
Abstrak: Pendidikan anak usia dini merupakan tahap yang penting untuk pengembangan kemampuan anak untuk bersekolah. Usia dini menajdi fase terbaik bagi anak untuk menerima stimulasi sekaligus pembentukan karakter mereka di masa yang akan datang. Lingkungan fisikberperan penting dalam mendukung keberhasilan pembentukan perilaku anak-anak. Salah satunya melalui desain ruang-ruang kelas yang sesuai dengan dunia anak. Penelitian ini berusaha mengevaluasi penataan interior kelas dalam pembentukan perilaku anak serta pengaruhnya terhadap perilaku anak di Kelompok Bermain/Taman Kanak-Kanak Islam Sakha. Penelitian ini menggunakan metode deskriptif dengan pendekatan kualitatif dan teknik observasi terhadap berbagai aspek penataan lingkungkan fisik kelas. Hasil penelitian menyimpulkan bahwa beberapa aspek penataan interior kelas di Kelompok Bermain/Taman Kanak-Kanak Islam Sakha, seperti keleluasaan pandangan dan kenyamana, belumlah sesuai dengan standar, sedangkan penataan interior kelas telah mempengaruhi perilaku anak-anak dengan mekanisme penghalang dan pengundang beberapa perilaku tertentu anak untuk membentuk kepribadian mereka.
\end{abstract}

Kata Kunci: penataan interior kelas, perilaku anak, taman kanak-kanak 


\section{PENDAHULUAN}

Program pendidikan anak usia dini (PAUD) yang dilaksanakan dalam bentuk Kelompok Belajar/Taman Kanak-Kanak (KB/TK) merupakan tahapan pendidikan yang penting untuk mengembangkan kemampuan anak sesuai dengan tahap perkembangannya (developmental task) dan menyiapkan anak usia dini untuk siap bersekolah. Usia sampai dengan enam tahun yang sering disebut sebagai "usia emas" (golden age) merupakan fase yang potensial dalam perkembangan anak untuk menerima stimulasi, sekaligus fase yang sangat menentukan untuk pengembangan kualitas manusia di masa yang akan datang (Ariestadi, 2012). Dengan demikian, bentuk stimulasi yang diberikan dalam proses pembelajaran di $\mathrm{KB} / \mathrm{TK}$ perlu dirancang dengan sebaik-baiknya.

Keberhasilan pembentukan perilaku anak selain didukung oleh lingkungan psikis, juga perlu didukung oleh lingkungan fisik (Ariestadi, 2012). Selain kreatifitas guru dan ketersediaan materi untuk pengembangan anak, kondisi di sekeliling tempat belajar yang responsif pun harus disetting untuk kebutuhan anak, termasuk setting ruang dalam dan isinya yang secara fisik dan mental menarik bagi anak (Montessori, 1995). Hal itu dapat dilakukan melalui desain ruang-ruang kelas yang dibentuk seperti tempat tinggal dan segala isinya dalam ukuran anak-anak atau dengan kata lain, merefleksikan dunia anak sesuai dengan ukuran anak-anak.

Lingkungan fisik kelas berpengaruh besar dalam membentuk suasana kondusif yang memotivasi murid untuk belajar sehingga penataan interior dan perlengkapan belajar yang ada di kelas hendaknya mampu membantu meningkatkan motivasi belajar murid (Murtiasih, 2014). Sebagaimana diungkapkan dari hasil penelitian Cetinkaya dan Oruc didalam Murtiasih (2014) bahwa lingkungan fisik belajar berpengaruh baik terhadap motivasi mahasiswa dalam belajar bahasa, selain status sosial ekonomi. Artinya, tingkat motivasi mahasiswa universitas swasta terbukti signifikan lebih tinggi dari mahasiswa universitas umum, karena lingkungan belajar universitas swasta yang diteliti lebih baik dari universitas umum.

\subsection{Lingkungan Fisik}

Lingkungan fisik dapatlah dimaknai sebagai perwujudan dalam kondisi fisik bangunan, interior beserta segala isinya, dan sebagainya (Astrini, 2005) .

\section{Prinsip Menata Lingkungan Fisik Kelas}

Terdapat lima prinsip dalam penataan lingkungan fisik kelas (Fernanda, Asikin, \& Laksmiwati, 2015), antara lain:

\section{a. Keleluasaan pandangan (visibility)}

Keleluasaan pandangan berarti penempatan dan penataan barang-barang di dalam kelas tidak mengganggu pandangan anak.

b. Mudah dicapai (accesibility)

Mudah dicapai berarti ruangan harus ditata sehingga anak mudah dalam meraih/mengambil benda-benda yang dibutuhkan saat berlangsungnya proses pembelajaran. Sirkulasi yang merupakan pengarahan dan pembimbingan jalan yang terjadi dalam ruang juga termasuk bagian dari aksesibilitas. Kemampuan anak menjangkau barang yang berada di meja atau rak adalah pada ketinggian antara 121-133 cm (Astrini, 2005). Gambaran jangkauan anak dapat dilihat pada gambar 1.

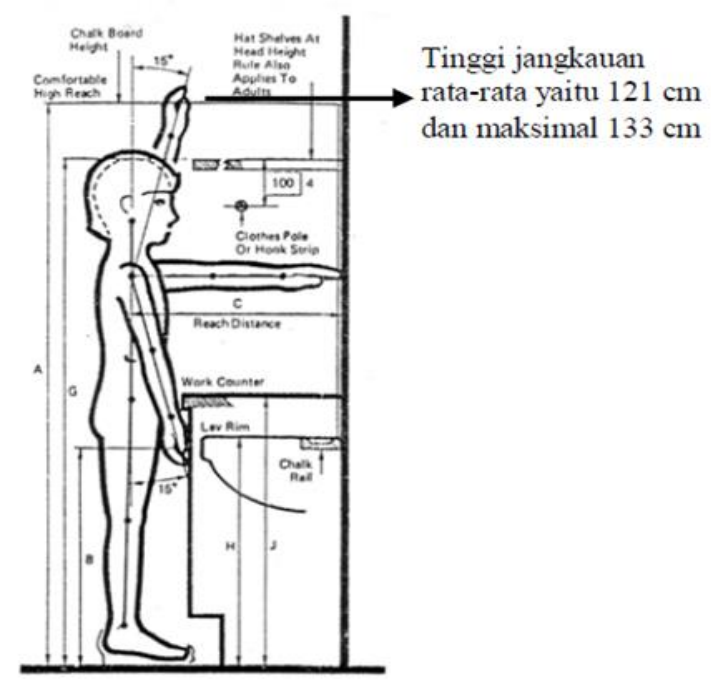

Gambar 1. Tinggi jangkauan anak terhadap tinggi meja dan rak (Sumber: Astrini, 2005)

c. Fleksibilitas ruang

Keluwesan berarti ruangan dapat difungsikan untuk berbagai kegiatan dengan karakter yang berbeda dan pengubahan susunan ruang dapat dilakukan tanpa mengubah tatanan bangunan. Keluwesan / fleksibilitas terdiri atas tiga konsep, yaitu ekspansibilitas (perluasan ruang), konvertibilitas (perubahan tata atur), dan versatibilitas (multi fungsi).

d. Kenyamanan

Kenyamanan merupakan kondisi perasaan yang berkaitan dengan temperatur / penghawaan ruang, terang, suara, dan kepadatan kelas.

e. Keindahan

Keindahan berkaitan dengan usaha menata ruang kelas yang menyenangkan dan kondusif bagi kegiatan belajar. Ruangan kelas yang indah dan menyenangkan dapat berpengaruh positif pada sikap dan tingkah laku siswa terhadap kegiatan pembelajaran yang dilaksanakan.

\section{Organisasi Ruang}

Bentuk organisasi ruang dapat dibedakan menjadi lima (Prasetya, 2012), sebagai berikut:

a. Organisasi ruang terpusat, yaitu sebuah ruang yang terletak di tengah dengan ukuran yang besar dan dominan bagi ruang di sekelilingnya, organisasi ini mengarah ke dalam.

b. Organisasi ruang linier, yaitu susunan ruang-ruang 
yang berderet memanjang dan saling berhubungan.

c. Organisasi ruang radial, yaitu perpaduan antara organisasi terpusat dan linier yang mengarah ke luar.

d. Organisasi ruang mengelompok, merupakan komposisinya dari ruang-ruang yang berbeda ukuran, bentuk, dan fungsi namun berulang-ulang.

e. Organisasi ruang secara grid, terdiri atas sejumlah ruang yang posisinya tersusun dengan pola grid (3 dimensi), antar ruang membentuk hubungan dari seluruh fungsi posisi dan sirkulasi.

\section{Warna}

Pengaruh warna terhadap psikologi manusia dapat dilihat pada tabel 1.

Tabel 1. Pengaruh warna terhadap psikologi manusia

\begin{tabular}{cl}
\hline Warna & \multicolumn{1}{c}{ Pengaruh Psikologi } \\
\hline Merah & $\begin{array}{l}\text { Memberikan inspirasi kekuatan, energy, } \\
\text { agresi, nafsu, cinta, dan kehangatan }\end{array}$
\end{tabular}

Kuning Memberi efek positif, meningkatkan rasa percaya diri, membentuk rasa optimis, dan melambangkan harapan; menstimulasi otak serta menjadikan manusia lebih tegas dan waspada; jumlah cahaya terpantul lebih banyak dibandingkan warna-warna lain sehingga menarik perhatian

Orange Membawa sifat energik, ambisi, keceriaan; sikap yang menyenangkan, berhubungan dengan keamanan sensualitas, pemicu selera makan; melambangkan keramahan, keakraban, dan pemberi efek rasa aman

Hijau Memberikan efek tenang, rileks, mudah, dan menjadi sarana penyeimbang emosi seseorang

Biru Simbol kepercayaan, konsistensi, pemicu konsentrasi; namun, warna biru yang dominan dapat memberikan kesan kaku, tidak akrab, tidak punya ambisi, pemicu timbulnya keraguan

Coklat Identik dengan sifat alami; menggambarkan keseriusan, sifat yang dapat dipercaya, kehangatan; menunjukkan kelembutan

Hitam Menunjukkan kesan mewah, mempesona, anggun, dan teguh; namun, juga memberi kesan negatif seperti kesedihan, keputusasaan, dosa, ketakutan, kehampaan, identik dengan warna kematian

Putih Melambangkan kesucian, kelembutan, ketepatan, kebersihan; memberi kesan luas, bersih, dan ekostik pada sebuah ruang

Sumber: Fransisca, (2012)

\section{Pengaturan Tempat Duduk}

Pengaturan tempat duduk pada ruang kelas mempunyai banyak pengaruh. Terdapat lima pola pengaturan tempat duduk (Muman \& Hadiansyah, 2016), yaitu rectangle, semi-circle, horse-shoe, converence table, dan round table (gambar 2).

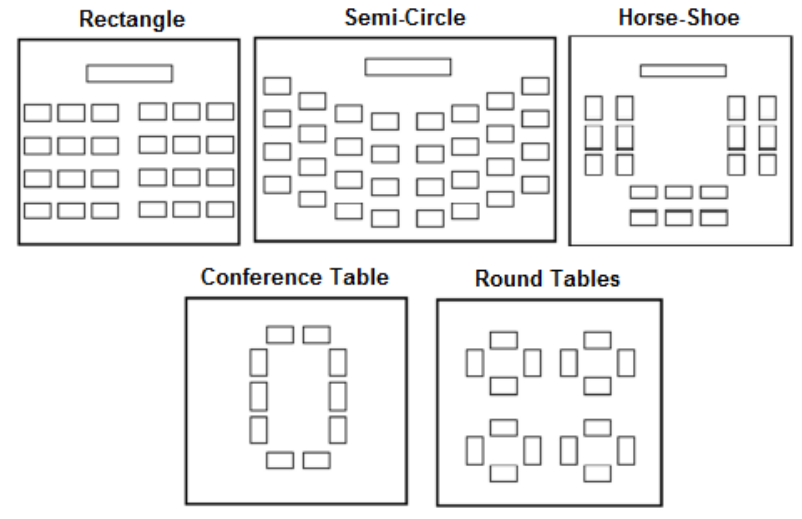

Gambar 2. Pola Pengaturan Tempat Duduk (Sumber: Muman \& Hadiansyah, 2016)

\section{Sirkulasi Ruang}

Ruangan ideal adalah ruangan dengan luasan 40$50 \mathrm{~m}^{2}$ dan diisi oleh 24 orang siswa. Namun, dapat juga menggunakan batasan minimum 0,9 $\mathrm{m}^{2}$ untuk tiap anak bila tidak memungkinkan (Prasetya, 2012).

\section{Pengendalian Kebisingan oleh Dinding Ruangan}

Untuk mencegah perambatan bunyi antar ruang dapat melalui dinding pembatas yang tidak disertai dengan jendela atau lubang ventilasi, hanya terbuat dari dinding utuh yang terbuat dari material berat-tebalmasif sehingga lebih mudah menentukan kemampuan insulasinya (Mediastika, 2009). Penggunaan material pembatas yang berlapis-lapis akan memaksimalkan refraksi sehingga bidang pembatas menjadi peredam yang semakin baik.

Penggunaan pembatas berlapis yang diaplikasikan pada partisi atau dinding dapat dibedakan menjadi dua, yaitu:

a. Partisi tunggal atau berlapis tanpa rongga antara Partisi atau dinding berlapis tanpa rongga udara antar lapisan memiliki karakteristik seperti halnya partisi tunggal. Kemampuan redaman bidang partisi tergantung pada frekuensi bunyi yang mengenai partisi dan massa partisi $\left(\mathrm{kg} / \mathrm{m}^{2}\right)$. Semakin besar massa bidang partisi dan semakin tinggi frekuensi bunyi yang hendak diredam, semakin besar pula kemampuan redam dan angka redam yang dihasilkan. Secara teoritis kemampuan redaman dinding akan meningkat $6 \mathrm{~dB}$ ketika massanya meningkat dua kali lipat.

b. Partisi atau dinding ganda dengan rongga antara.

Ketika dua material pembatas digunakan bersama dengan menempatkan rongga udara di antaranya maka kemampuan redam yang diperoleh secara umum lebih besar dibanding pembatas tunggal atau berlapis tanpa rogga. Semakin tebal rongga yang ada, semakin besar kemampuan redamnya. Untuk alasan kekuatan konstruksi dan efektivitas luas ruang, tebal rongga maksimum disarankan $20 \mathrm{~cm}$ saja. 


\subsection{Hubungan antara Lingkungan dan Perilaku}

Pembentukan dan perkembangan perilaku manusia dapat dipengaruhi oleh kenyamanan bertempat tinggal dan berkegiatan di dalam ruangaruangan yang dimiliki sebuah bangunan (Astrini, 2005). Terdapat empat cara lingkungan mempengaruhi perilaku (Prabowo, 1998), yaitu:

a. Lingkungan menghalangi perilaku, sehingga menimbulkan keterbatasan kita dalam melakukan sesuatu. Misalnya, tinggi meja akan mempengaruhi postur tubuh seseorang saat duduk; banyaknya orang di dalam kamar mempengaruhi perasaan nyaman seseorang, kegaduhan mempengaruhi jumlah suara yang terdengar oleh seseorang.

b. Lingkungan mengundang atau mendatangkan perilaku, menentukan bagaimana seseorang harus melakukan sesuatu. Misalnya, pada ruang tengah dengan kursi sandaran yang tegak dan dibungkus plastik agar selalu bersih membuat seseorang duduk dengan punggung tegak dan tidak mengotorinya; sebaliknya pada ruang tamu dengan kursi besar membuat seseorang duduk bersandar dan santai.

c. Lingkungan membentuk kepribadian. Perilaku yang dibatasi lingkungan dapat menjadi bagian tetap dari diri yang menentukan arah perkembangan kepribadian pada masa yang akan datang. Misalnya, seorang anak yang belajar di ruangan kelas terbuka, tanpa ada deretan bangku yang menghadap guru, dan ruangan penuh dengan kegiatan yang dapat diikuti semua anak, pada tahun pertama sekolahnya, kemungkinan akan memandang bahwa belajar bukan untuk menyerap informasi dari orang yang ahli dalam bidangnya tetapi sebagai proses pemuasan rasa keingintahuannya. Dalam proses ini kepribadian anak akan dapat terbentuk.

d. Lingkungan akan mempengaruhi citra diri. Direktur merasa betapa penting dirinya dari semua benda di sekitarnya - lukisan di dinding dan karpet di lantai. Demikian juga, seorang anak kota tahu bahwa cat yang sudah melepuh, kumuh, dan bau busuk merupakan ketakberdayaan dan kemelaratan.

\subsection{Perkembangan dan Pertumbuhan Manusia serta Implikasi Desain pada Periode Kanak- Kanak}

\section{Perkembangan}

Perkembangan merupakan perubahan-perubahan psikologis atau mental yang dialami individu dalam proses menjadi dewasa, perubahan-perubahan tersebut terbentuk ketika seluruh aspek kepribadian individu semakin terdeferensi tetapi segala aspek yang berkembang itu terorganisasi menjadi satu totalitas (Prabowo, 1998). Tahap perkembangan kanak-kanak terbagi menjadi dua (Prabowo, 1998), yaitu periode kanak-kanak awal (early childhood) dan periode kanak-kanak akhir (late childhood) .
Periode kanak-kanak awal digolongkan pada anak yang berusia usia 2-6 tahun, sedangkan periode kanak-kanak akhir digolongkan pada anak yang berusia 6 tahun sampai organ-organ seksualnya masak. Kemasakan seksual anak sangat bervariasi baik antar jenis kelamin maupun antar budaya yang berbeda. Secara umum, diambil patokan 12-13 tahun untuk wanita dan 14-15 tahun untuk laki-laki.

Ciri perilaku yang menonjol pada pada periode kanak-kanak awal adalah semakin baiknya penguasaan terhadap tangan dan kakinya, bahkan anak sudah cenderung secara tetap mengunakan satu tangan untuk melakukan satu pekerjaan (handness). Kemampuan bahasa lebih baik, termasuk mengucapkan kata-kata, susunan kalimatnya, dan frekuensi bicaranya. Pada usia ini anak juga sudah terlibat dalam pemainan-permainan yang lebih berstruktur dengan teman-teman sebayanya.

Di akhir periode kanak-kanak awal, anak sudah bisa diatur oleh orang lain dan berinteraksi sebagai teman dengan anak-anak sebayanya. Perkembangan ini menentukan kesiapan anak untuk masuk sekolah.

Perkembangan fisik mulai berjalan lambat, tetapi pada usia ini anak mulai belajar banyak keterampilan lain, seperti keterampilan-keterampilan yang diajarkan di sekolah (school skills), bermain (play skills), dan mengurus dirinya sendiri.

\section{Pertumbuhan}

Pertumbuhan berarti pergantian-pergantian fisik/biologis ke arah kematangan fisiologis, yaitu dapat berfungsinya organ-organ tubuh secara optimal. Pada periode pertumbuhan, proses tersebut hanya sekali saja seumur hidup dan tidak dapat diulang. Perubahan fisik bila dilihat dari pertumbuhan tubuh dapat diukur melalui tinggi badan, sebagaimana disajikan pada tabel 2.

Tabel 2. Standar tinggi badan anak sesuai usia

\begin{tabular}{ccc}
\hline \multirow{2}{*}{$\begin{array}{c}\text { Usia } \\
\text { (tahun) }\end{array}$} & \multicolumn{2}{c}{ Tinggi Badan (cm) } \\
\cline { 2 - 3 } & Anak Laki-Laki & Anak Perempuan \\
\hline 1 & 71,7 & 69,8 \\
2 & 81,5 & 79,2 \\
3 & 89,0 & 87,8 \\
4 & 95,8 & 95,0 \\
5 & 102,0 & 101,1 \\
6 & 107,7 & 106,6 \\
7 & 113,0 & 111,8 \\
8 & 118,1 & 116,9 \\
9 & 122,9 & 122,1 \\
10 & 127,7 & 127,5 \\
11 & 132,6 & 133,5 \\
12 & 137,6 & 139,8 \\
\hline
\end{tabular}

Sumber: Putri, (2016) 


\section{Implikasi Desain}

a. Ruangan untuk Bergerak

Semakin baiknya fungsi motorik berupa penguasan terhadap tangan dan kakinya, menyebabkan anak akan makin mengenal dunia luar di sekelilingnya. Anak sudah dapat berbicara dan berjalan, sehingga ketergantungan dengan orang lain semakin berkurang. Untuk mewadahi aktivitas-aktivitas ini, diperlukan ruang (baik di dalam maupun di luar), sehingga anak akan memperoleh sesuatu yang berharga sesuai dengan kebutuhannya.

b. Playground

Kecenderungan berkumpul dengan sebayanya (peer group) dan belajar bermain (play skills) membawa implikasi desain tertentu. Bermain bagi anak adalah sesuatu bagian penting bagi perkembangan aspek-aspek kognitif, fisik, sosial, dan emosi (Prabowo, 1998). Melalui bermain anak akan banyak belajar tentang dirinya dan dunianya.

\section{METODE PENELITIAN}

Metode dalam penelitian ini adalah deskriptif kualitatif. Metode deskriptif merupakan metode penelitian untuk menggambarkan keadaan atau kejadian (Prasetya, 2012), sedangkan pendekatan kualitatif merupakan pendekatan secara utuh atas objek penelitian yang berupa sebuah peristiwa dengan instrumen kunci dalam penelitian adalah peneliti sendiri, kemudian hasil pendekatan dijelaskan dengan penjabaran kata-kata berdasarkan data empiris yang didapatkan dan pendekatan ini lebih menekankan makna daripada generalisasi (Muhammad, 2013).

Metode deskriptif digunakan untuk memberikan gambaran penataan interior di KBTK Islam Sakha berdasarkan hasil oservasi, meliputi prinsip-prinsip menata lingkungkan fisik kelas yang meliputi keleluasaan pandangan (visibility), mudah dicapai (accesibility), keluwesan (fleksibilitas ruang), kenyamanan, dan keindahan. Mengingat interior ruang kelas KBTK Islam Sakha sebagai objek penelitian bersifat tipikal, maka satu kelas dipilih sebagai sampel, yaitu TK B Musa. Pendekatan kualitatif dalam penelitian ini digunakan untuk mengevaluasi kesesuaian antara teori dengan penataan interior kelas dalam pembentukan perilaku anak di KBTK Islam Sakha. Selanjutnya, dari hasil evaluasi, diidentifikasi pengaruh cara penataan interior ruang kelas mempengaruhi perilaku anak.

\section{HASIL DAN PEMBAHASAN}

\subsection{Gambaran Umum Kelas}

KBTK Islam Sakha memiliki fasilitas kelas sebanyak lima ruang tipikal dan berukuran sama, yaitu $3 \times 6 \mathrm{~m}^{2}$. Organisasi ruang berbentuk linier dan berorientasi ke arah timur. Kondisi interior ruang kelas TK B Musa dapat dilihat pada gambar 3.

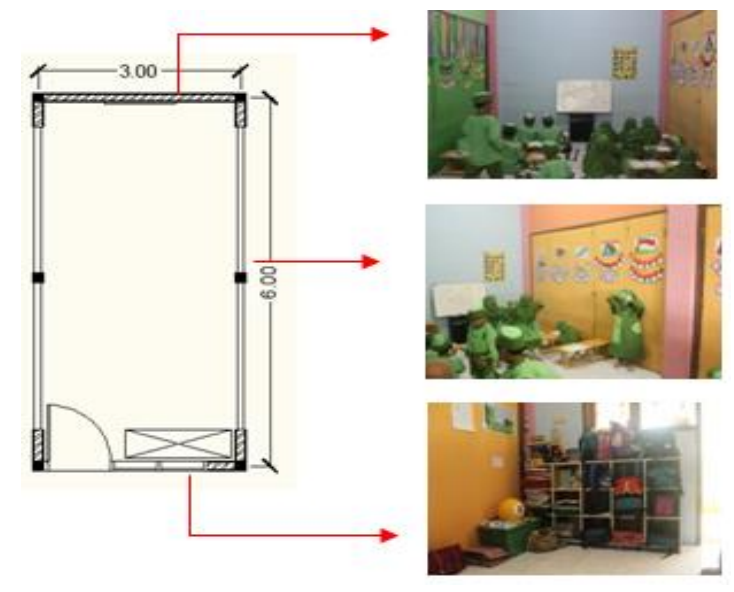

Gambar 3. Interior Ruang Kelas TK B Musa di KBTK Islam Sakha (Sumber: Dokumentasi penulis, 2018)

\subsection{Evaluasi Penataan Interior Kelas}

\section{Keleluasaan Pandangan (Visibility)}

Perabot di kelas TK B Musa KBTK Islam Sakha terdiri atas papan tulis, meja lipat, dan rak yang digunakan untuk meletakkan perlengkapan pembelajaran dan tas peserta didik. Penempatan papan tulis dan rak, selalu berada di tempat yang sama, sedangkan meja lipat hanya digunakan saat dibutuhkan dengan penataan tertentu menyesuaikan dengan kegiatan kelas. Untuk kegiatan individu, meja lipat ditata dengan pola rectangel dengan pengelompokan anak berdasarkan jenis kelaminnya secara berbanjar (laki-laki di sisi selatan dan perempuan di sisi barat, atau sebaliknya), sedangkan untuk kegiatan berkelompok, meja lipat ditata dengan pola round tables, sebagaimana terlihat pada gambar 4. Dengan penataan perabot dan pola duduk tersebut, secara umum tidak ada perabot yang mengganggu pandangan anak dalam berkegiatan di dalam kelas.

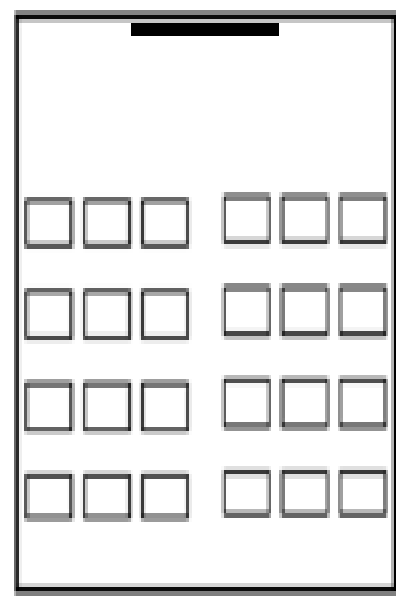

(a)

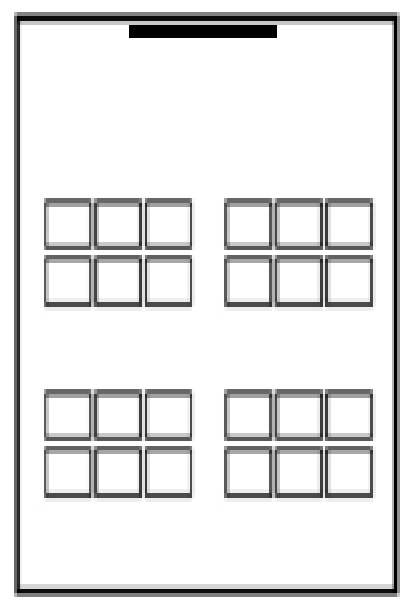

(b)
Gambar 4. Pola Penataan Meja Lipat di Kelas TK B Musa KBTK Islam Sakha: (a) Rectangle, (b) Round Tables (Sumber: hasil observasi, 2018) 
Posisi duduk anak dengan pola penataan meja lipat berbentuk rectangle mempunyai kelebihan dalam mengarahkan fokus anak. Pada pola ini, guru di depan kelas akan menjadi vocal point dan lebih leluasa bergerak terutama saat menggunakan alat peraga. Pola penataan ini juga efektif untuk ruangan yang sempit, karena fleksibel dalam pengaturan ke arah memanjang atau melebar. Namun, pola penataan rectangle mempunyai kelemahan bagi anak yang berada di barisan belakang ketika penataan diatur ke arah memanjang. Anak di barisan belakang akan jarang berinteraksi dengan guru, sehingga guru pperlu menyesuaiakan posisi berdirinya agar terjangkau anak-anak. Selain itu, teman yang berada di barisan depannya dapat menghalangi jangkauan pandang anak (Valentia, Wibowo, \& Wondo, 2013).

\section{Aksesibilitas}

Dalam sistem pendidikan di KBTK Islam Sakha, sekolah mengajarkan anak didiknya untuk hidup tertib dimulai dari anak tiba di sekolah sampai dengan pulang sekolah, salah satunya pembiasaan meletakkan tas di rak yang berada di dekat pintu masuk. Alur kegiatan anak pada pembiasaan ini adalah masuk kelas, kemudian meletakkan tas di rak, lalu duduk mengelompok sesuai dengan jenis kelaminnya dan mengikuti arahan guru, selanjutnya mengambil tas pada jam istirahat dengan kegiatan makan bekal dan kembali meletakkan tas di rak saat jam istirahat berakhir, lalu kembali duduk mengikuti arahan guru (melanjutkan kegiatan belajar), kemudian anak dipersiapkan keluar kelas satu per satu mengambil tasnya dari rak saat waktunya pulang. Alur sirkulasi anak dapat dilihat pada gambar 5. Dari segi alur sirkulasi anak dalam kelas, posisi rak yang dekat dengan pintu sangat mendukung proses pembiasaan hidup tertib.

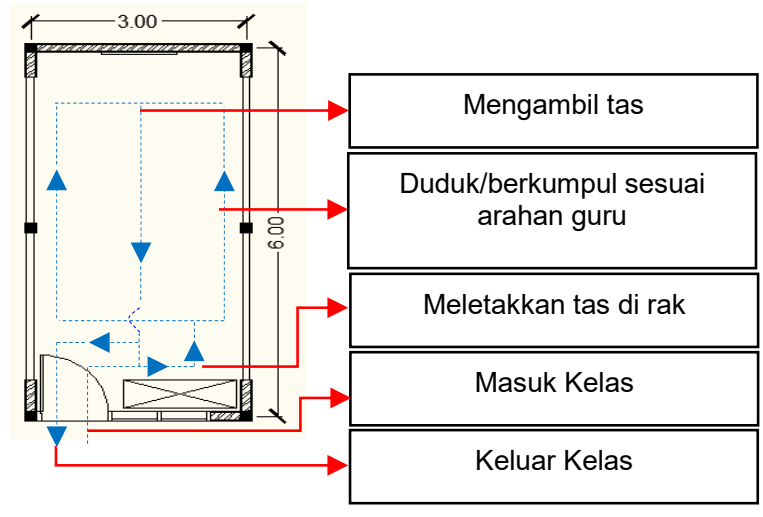

Gambar 5. Alur Sirkulasi di Kelas TK B Musa (Sumber: hasil analisis, 2018)

Dari segi ukuran, rak untuk meletakkan tas yang berukuran panjang $1,8 \mathrm{~m}$ dan tinggi $1,5 \mathrm{~m}$ yang terletak di setiap ruang kelas KBTK Islam Sakha termasuk mudah dijangkau bagi anak usia 3-6 tahun (usia PAUD). Kemudahan jangkauan anak untuk meletakkan tasnya di rak dengan ketinggian rak 1,5 m tersebut juga sesuai dengan standar tinggi anak usia
3-6 tahun yang mempunyai tinggi antara 89,0-107,7 $\mathrm{cm}$ untuk anak laki-laki dan antara 87,8-106,6 cm untuk anak perempuan (Astrini, 2005), serta sesuai dengan kemampuan jangkauan anak, yaitu pada ketinggian antara $121-133 \mathrm{~cm}$, sebagaimana dapat dilihat pada tabel 2 dan gambar 1.

\section{Fleksibilitas Ruang}

Penerapan tiga konsep fleksibilitas--perluasan ruang, perubahan tata atur, dan multi fungsi di KBTK Islam Sakha dilakukan melalui pengelolaan ruang kecil dan ruang besar dengan sistem buka-tutup sekat antar ruang. Dari lima kelas (kelas play group, TK A Ibrahim, TK A Ismail, TK B Muhammad, dan TK B Musa) yang terorganisasi linier, antar ruang kelas dibatasi dengan sekat berupa pintu lipat yang dapat dibuka tutup menyesuaikan kebutuhan ruang kegiatan anak, sehingga pada kondisi tertentu ruang kegiatan dapat dikondisikan dengan ukuran $3 \times 6 \mathrm{~m}^{2}$ sampai dengan $15 \times 6 \mathrm{~m}^{2}$. Perletakkan pintu lipat antar ruang dapat dilihat pada gambar 6 .

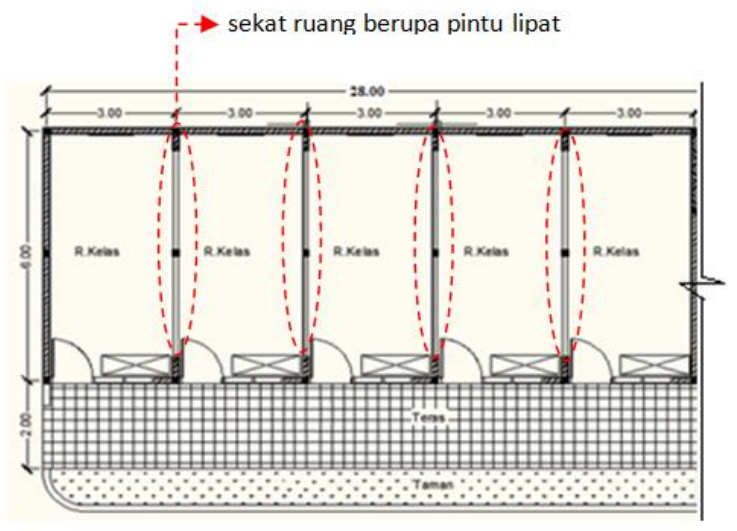

Gambar 6. Pengelolaan Ruang Kelas Kecil dan Besar dengan Pintu Lipat (Sumber: hasil observasi, 2018)

\section{Kenyamanan \\ Penghawaan}

Pada semua iklim terutama pada iklim lembab, ukuran luas bukaan adalah $10-15 \%$ dari total lantai bangunan (Lechner, 2014). Bila digunakan nilai 10\%, kebutuhan luas bukaan di setiap ruang kelas KBTK Islam Sakha adalah $1,8 \mathrm{~m}^{2}$ dengan perhitungan sebagai berikut:

$$
A_{\text {bukaan }}=10 \% \times 3 \mathrm{~m} \times 18 \mathrm{~m}=1,8 \mathrm{~m}^{2}
$$

Dari hasil observasi, diketahui bahwa ukuran bukaan di ruang kelas KBTK Islam Sakha seluas 0,6 $\times 1 \mathrm{~m}^{2}$ dengan tipe awning windows yang terdiri atas 1 lubang bukaan. Hal ini berarti ukuran bukaan ruang kelas di KBTK Islam Sakha tidak memenuhi kebutuhan penghawaan alami. Berdasarkan hasil analisis matematis kebutuhan penghawaan alami yang tidak terpenuhi oleh ukuran lubang bukaan yang ada, pemilihan penggunaan $A C$ di perlukan untuk memenuhi kebutuhan kenyamanan penghawaan. Sistem penghawaan yang digunakan adalah 
penghawaan buatan dengan menggunakan AC tipe split, diletakkan di sudut atas sisi timur dinding, di atas jendela ruang kelas, sebagaimana dapat dilihat pada gambar 7. Untuk ukuran temperatur yang dipasang berkisar antara $25^{\circ}-27^{\circ} \mathrm{C}$ (menyesuaikan permintaan dan kegiatan anak didik dalam ruang).

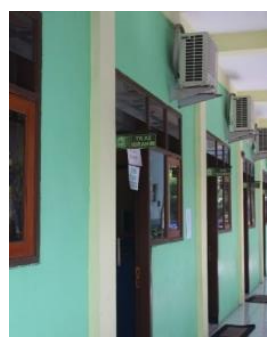

(a)

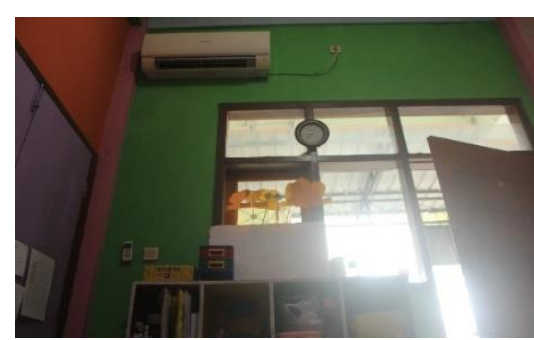

(b)
Gambar 7. Sistem Penghawaan di Kelas TK B Musa KBTK Islam Sakha: (a) Outdoor unit, (Sumber: Dokumentasi penulis, 2018)

Ditinjau dari letak indoor unit AC dan geometri ruang, aliran udara yang terjadi di dalam ruangan, secara vertikal tersesebar ke tengah ruang di sisi utara dan secara horizontal berputar berlawanan arah jarum jam dengan tekanan yang lebih rendah di sisi barat, selatan, dan timur. Gambaran aliran udara secara vertikal dan horizontal dari indoor unit $A C$ di dalam ruang dapat dilihat pada gambar 8. Berdasarkan penataan duduk anak didik yang terpusat di tengah ruangan, aliran udara yang terjadi sudah kondusif. Hasil wawancara dengan anak didik juga menyatakan bahwa mereka tidak merasakan kepanasan atau kedinginan selama berkegiatan di dalam kelas. Dengan demikian, dapat disimpulkan bahwa anakanak merasa nyaman dengan penataan $A C$ di ruang kelas tersebut.
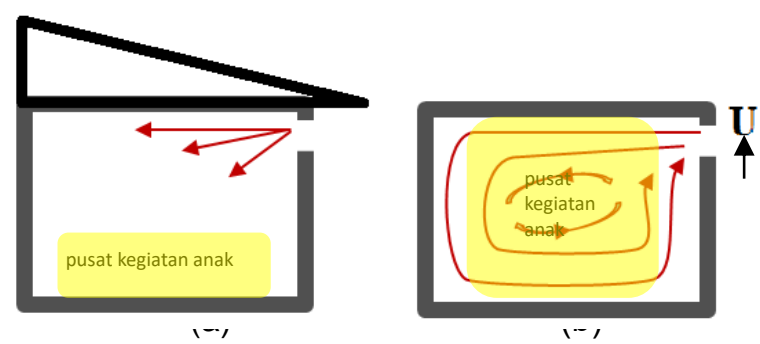

Gambar 8. Arah Aliran Udara dari Indoor Unit AC: (a) Vertikal, (b) Horizontal (sumber: analisis, 2018)

\section{Suara}

Antar ruang kelas di batasi dengan pintu lipat dari material triplek (tanpa peredam dalam rongga pintu). Pintu lipat ini dipasang di sepanjang dinding ruang yang saling bersebelahan (di sisi terpanjang ruang) setinggi $2 \mathrm{~m}$ (gamabr 9). Berdasarkan material pembatas ruang, triplek merupakan material yang bersifat ringan-tipis-tidak masif. Karena pembatas ruang berupa partisi dengan rongga antara dengan rongga udara diantaranya, pembatas ruangan ini tidak dapat menjadi peredam kebisingan. Ruang dengan aktivitas pembelajaran dan anak-anak sebagai pengguna ruangnya, merupakan ruang yang mempunyai sumber kebisingan tinggi. Dari hasil observasi, didapat bahwa ruang kelas terasa bising. Hal ini, dapat mengganggu kenyamanan bagi ruang di kanan/kirinya.

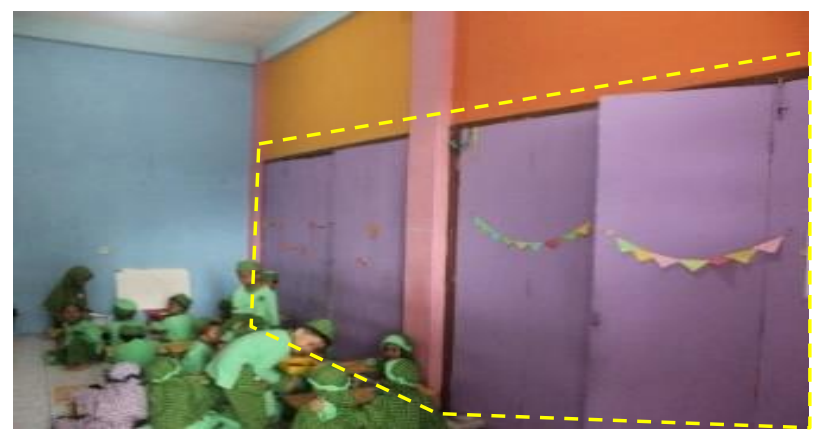

(a)

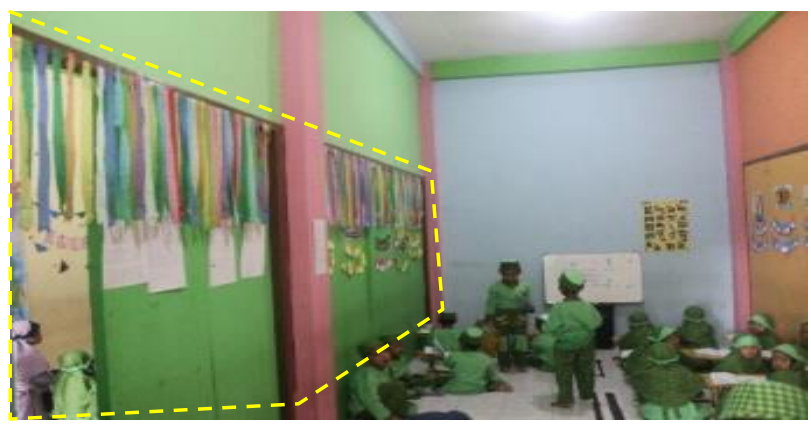

(b)

Gambar 9. Material Penyekat Antar Ruang Kelas: (a) TK B Muhammad, (b) TK B Musa (Sumber: Dokumentasi penulis, 2018)

\section{Kepadatan kelas}

Jumlah anak didik KBTK Islam Sakha per kelas antara 20-25 anak. Jika mengikuti standar yang menyatakan bahwa batasan minimum $0,9 \mathrm{~m}^{2}$ untuk tiap anak (Prasetya, 2012), maka luasan ruang untuk 25 anak baru akan terpenuhi jika dua kelas digunakan oleh satu kelompok kelas di KBTK Islam Sakha. Artinya, rasio antara kelompok anak didik berdasarkan jenjang pendidikan di KBTK Islam Sakha (Playgroup, TK A, TK B) dengan rasio ruang ideal satu berbanding dua, atau jumlah anak dalam ruang dibatasi maksimal sebanyak 20 anak untuk aktivitas belajar yang dilakukan di dalam kelas. 
Tabel 3. Pengaruh Penataan Interior Kelas dalam Pembentukan Perilaku Anak di KBTK Islam Sakha

\begin{tabular}{|c|c|c|c|}
\hline & Menghalangi Perilaku & $\begin{array}{c}\text { Mengundang/ } \\
\text { Mendatangkan Perilaku }\end{array}$ & Membentuk Kepribadian \\
\hline $\begin{array}{c}\text { Keleluasaan } \\
\text { pandangan } \\
\text { (visibility) }\end{array}$ & $\begin{array}{l}\text { Negatif: } \\
\text { Pola duduk rectangle } \\
\text { memanjang berakibat } \\
\text { terhalangnya pandangan } \\
\text { anak yang duduk di bagian } \\
\text { belakang, sehingga anak } \\
\text { lebih lambat menerima } \\
\text { informasi dari guru }\end{array}$ & & \\
\hline $\begin{array}{l}\text { Mudah dicapai } \\
\text { (accesibility) }\end{array}$ & & & $\begin{array}{l}\text { Positif: } \\
\text { Pembiasaan meletakkan } \\
\text { tas di rak yang mudah } \\
\text { dijangkau membentuk } \\
\text { pribadi yang disiplin dan } \\
\text { mandiri }\end{array}$ \\
\hline $\begin{array}{l}\text { Keluwesan } \\
\text { (fleksibilitas } \\
\text { ruang) }\end{array}$ & & $\begin{array}{l}\text { Positif: } \\
\text { Fleksibilitas ruang yang dapat } \\
\text { mengakomodasi berbagai } \\
\text { bentuk kegiatan anak } \\
\text { memperkaya pengalaman } \\
\text { belajar dengan kedinamisan } \\
\text { suasana ruang }\end{array}$ & \\
\hline Kenyamanan & $\begin{array}{l}\text { Negatif: } \\
\text { a. Kebisingan akibat sekat } \\
\text { antar ruang berupa pintu } \\
\text { lipat dari material triplek } \\
\text { dengan rongga antara } \\
\text { adalah udara dapat } \\
\text { menurunkan } \\
\text { konsentrasi, bahkan } \\
\text { menimbulkan stress } \\
\text { b. Ketersediaan ruang } \\
\text { gerak yang sangat } \\
\text { minim, membatasi } \\
\text { proses pengembangan } \\
\text { keterampilan motorik } \\
\text { kasar anak }\end{array}$ & $\begin{array}{l}\text { Positif: } \\
\text { Terpenuhinya kebutuhan } \\
\text { penghawaan ruang } \\
\text { menambah semangat dan } \\
\text { keceriaan anak }\end{array}$ & \\
\hline Keindahan & & $\begin{array}{l}\text { Positif: } \\
\text { Aplikasi warna pada dinding } \\
\text { kelas menambah semangat } \\
\text { belajar anak }\end{array}$ & $\begin{array}{l}\text { Positif: } \\
\text { a. Aplikasi warna pada } \\
\text { lantai kelas } \\
\text { mendukung } \\
\text { pembentukan perilaku } \\
\text { hidup bersih } \\
\text { b. Pemasangan karya } \\
\text { buatan anak didik } \\
\text { yang menjadi dekorasi } \\
\text { kelas, menumbuhkan } \\
\text { kepercayaan diri anak }\end{array}$ \\
\hline
\end{tabular}

(Sumber: Hasil analisis, 2018)

\section{Keindahan}

\section{Warna Interior Kelas}

Warna-warna yang diaplikasikan pada dinding kelas antara lain warna biru, oren, kuning, hijau, merah muda, sedangkan pada plafon dan lantai adalah warna putih. Dari segi pengaruh terhadap psikologi anak sebagaimana di sebutkan pada tabel 1, warna-warna pada dinding, plafon, dan lantai memberi efek positif. Warna-warna pada dinding dapat menambah semangat belajar anak, sedangkan warna pada lantai dapat mendukung pembentukan perilaku hidup bersih. 


\section{Dekorasi}

Dekorasi ruang biasannya di buat oleh guru atau hasil karya anak. Dekorasi yang bisanya di buat oleh guru berfungsi untuk media pembelajaran agar anak dapat menangkap pelajaran dengan mudah, sedangkan dekorasi yang hasil karya anak berfungsi sebagai apresiasi kepada anak dan meningkatkan motivasi belajar anak (gambar 10).

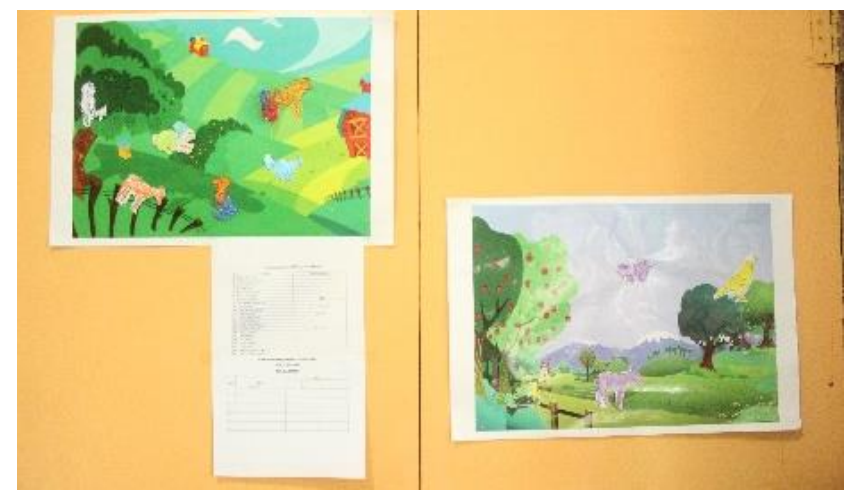

(a)

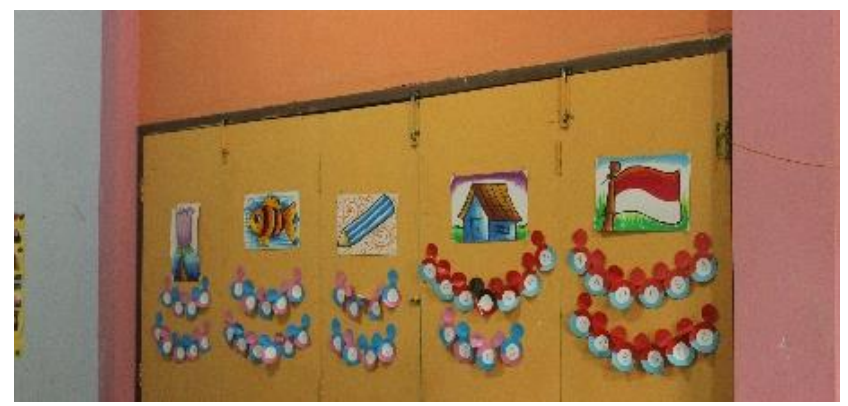

(b)

Gambar 10. Dekorasi buatan anak didik (a) dan buatan guru (b) (Sumber: Dokumentasi penulis, 2018)

\subsection{Identifikasi Pengaruh Penataan Interior Kelas dalam Pembentukan Perilaku}

Terdapat pengaruh positif dan negatif atas penataan interior kelas (tabel 3). Dari hubungan antara variabel penataan lingkungan fisik (interior kelas) dengan cara lingkungan mempengaruhi perilaku, pengaruh negatif menjadi tolak ukur perbaikan yang perlu dilakukan atas penataan interior di KBTK Islam Sakha. Pada penelitian ini, didapatkan hanya tiga cara lingkungan mempengaruhi perilaku dari pengaruh penataan interior, yaitu menghalangi perilaku, mengundang / mendatangkan perilaku, dan membentuk kepribadian, sedangkan cara lingkungan mempengaruhi citra diri tidak relevan dengan variabel penataan lingkungan fisik kelas yang digunakan dalam penelitian ini.

\section{KESIMPULAN}

Penataan interior kelas di KBTK Islam Sakha yang tidak sesuai dengan teori terdapat pada prinsip keleluasaan pandangan (visibility) dan kenyamanan. Ketidaksesuaian antara teori dengan prinsip keleluasaan pandangan (visibility) disebabkan oleh pola duduk, sedangkan pada prinsip kenyamanan disebabkan oleh sekat antar ruang yang materialnya tidak dapat meredam kebisingan dan disebabkan oleh ukuran ruang yang membatasi ruang gerak anak. Cara penataan interior kelas di KBTK Islam Sakha mempengaruhi perilaku anak adalah dengan menghalangi perilaku, mengundang/mendatangi perilaku, dan membentuk kepribadian. Cara menghalangi perilaku sebagai akibat pola duduk menjadikan anak lambat menerima informasi dari guru. Cara mengundang / mendatangkan perilaku yaitu dari fleksibilitas ruang yang memperkaya pengalaman belajar anak, dari kenyamanan penghawaan yang menambah semangat dan keceriaan, serta dari aplikasi warna pada dinding yang menambah semangat belajar anak. Cara membentuk kepribadian diperoleh dari penataan rak sehingga anak menjadi disiplin dan mandiri, dari warna lantai sehingga anak menjadi pembersih, dan dari dekorasi buatan anak sehingga anak menjadi percaya diri.

\section{REFERENSI}

Ariestadi, D. (2012). Kajian dan Pengembangan Standar Bangunan Taman Kanak-Kanak Sebagai Upaya Peningkatan Mutu Pendidikan Anak Usia Dini di Indonesia. Teknologi, Kejuruan, dan Pengajarannya, 33(2), 211-222. doi:10.17977/tk.v33i2.3057

Astrini, W. (2005). Pengaruh Interior Ruang Belajar dan Bermain Terhadap Kognitif Afektif dan Psikomotorik Anak di TT Negeri Pembina Malang. Dimensi Interior, 3(1), 1-16. doi:10.9744/interior.3.1.

Fernanda, G., Asikin, D., \& Laksmiwati, T. (2015). Interior Ruang Kelas Sekolah Dasar dengan Pendekatan Konsep Permainan Tradisional pada Program Full day School di Malang. Jurnal Mahasiswa Jurusan Arsitektur, 3(1). Retrieved from

http://arsitektur.studentjournal.ub.ac.id/index.php/j ma/article/view/71

Fransisca, D. (2012). Pengaruh Warna terhadap psikologi manusia. Retrieved 21 July 2018, from https://chooseandbuild.wordpress.com/2012/09/2 5/pengaruh-warna-terhadap-psikologi/

Lechner, N. (2014). Heating, cooling, lighting: Sustainable design methods for architects. John wiley \& sons.

Mediastika, C. E. (2009). Material Akustik - Pengendali Kualitas Bunyi pada Bangunan (I). Yogyakarta: Andi Offset.

Montessori, M. (1995). The Absorbent Mind (Reprint edition). New York: Holt Paperbacks.

Muhammad, A. A. (2013). Kesadaran Hukum Masyarakat Kampung Mahmud untuk Memiliki Sertifikat Atas Hak Ulayat: Studi Kasus Di Kampung Adat Mahmud Desa Mekarrahayu Kecamatan Marga Asih Kabupaten Bandung 
(Thesis). Universitas Pendidikan Indonesia, Bandung.

doi:/http://repository.upi.edu/406/10/S_PKN_0907 327_APPENDIX.pdf

Muman, D. K., \& Hadiansyah, M. N. (2016). Analisis Jarak dan Sudut Pandang Posisi Duduk pada Ruang Perkuliahan Terhadap Efektivitas Belajar Mahasiswa di Gedung Tokong Nanas Universitas Telkom. Idealog: Ide Dan Dialog Desain Indonesia, 1(2), 146-163. doi:10.25124/idealog.v1i2.849

Murtiasih, D. (2014). Pengaruh Lingkungan Fisik Kelas dan Dukungan Orang Tua Terhadap Motivasi Belajar Peserta Didik. Jurnal Pendidikan Administrasi Perkantoran, 4(1).

Prabowo, H. (1998). Arsitektur, Psikologi dan Masyarakat. Jakarta: Universitas Gunadharma.
Prasetya, N. (2012). Kajian Aspek Interior Ruang Belajar dan Bermain pada Taman Kanak-Kanak di Surakarta. Dimensi Interior, 10(1), 23-32. doi:10.9744/interior.10.1.23-32

Putri, R. R. (2016). Inilah Tinggi Badan Anak Indonesia Sesuai Usianya. Retrieved 19 July 2018, from https://www.klikdokter.com/infosehat/read/2698615/inilah-tinggi-badan-anakindonesia-sesuai-usianya

Valentia, V., Wibowo, M., \& Wondo, D. (2013). Konsep Perancangan Interior Ruang Kelas Sekolah Minggu Gereja Pantekosta di Indonesia (GPdl) di Sidoarjo. Intra, 1(2), 1-17. Retrieved from http://publication.petra.ac.id/index.php/desaininterior/article/view/1595 